\title{
Artigo Original / Original Paper Clado Mimosoide (Leguminosae-Caesalpinioideae) no Parque Estadual Mata da Pimenteira, Semiárido de Pernambuco, Brasil
}

\author{
Samara Silva de Matos ${ }^{1}$, André Laurênio de Melo ${ }^{2}$ \& Juliana Santos-Silva ${ }^{1,3}$
}

\begin{abstract}
Resumo
Este trabalho consiste em um estudo florístico-taxonômico do clado Mimosoide (Leguminosae Caesalpinioideae) realizado no Parque Estadual Mata da Pimenteira, primeira Unidade de Conservação em caatinga do estado de Pernambuco, localizado no município de Serra Talhada. As coletas mensais foram realizadas no período compreendido entre março de 2015 e março de 2016. Foram identificadas 14 espécies (nove gêneros): Anadenanthera colubrina, Chloroleucon dumosum, Desmanthus pernambucanus, Enterolobium timbouva, Mimosa arenosa var. arenosa, M. candollei, M. ophthalmocentra, M. modesta var. ursinoides, M. pigra var. pigra, M. tenuiflora, Neptunia plena, Parapiptadenia zehntneri, Piptadenia stipulacea e Senegalia tenuifolia. Características como número de folíolos, forma e localização de nectários, tipo de inflorescência, morfologia dos frutos e sementes foram essenciais para identificação dos táxons. São apresentados chave de identificação, descrições, comentários de distribuição geográfica e de afinidades taxonômicas das espécies.
\end{abstract}

Palavras-chave: Caatinga, Fabaceae, flora, taxonomia vegetal, unidade de conservação.

\section{Abstract}

This work consists of a floristic-taxonomic study of the Mimosoid clade (Leguminosae - Caesalpinioideae), carried out in Mata da Pimenteira State Park, the first Conservation Unit in the state of Pernambuco, located in the municipality of Serra Talhada. The collections were monthly and executed during the period from March 2015 to March 2016. There were 14 species distributed in nine genera: Anadenanthera colubrina, Chloroleucon dumosum, Desmanthus pernambucanus, Enterolobium timbouva, Mimosa arenosa var. arenosa, M. candollei, M. ophthalmocentra, M. modesta var. ursinoides, M. pigra var. pigra, M. tenuiflora, Neptunia plena, Parapiptadenia zehntneri, Piptadenia stipulacea e Senegalia tenuifolia. Characteristics such as number of leaflets, shape and location of nectars, type of inflorescence, fruit and seed morphology were essential for the identification of taxa. Key identification, descriptions, comments of geographic distribution and taxonomic affinities of the species are presented.

Key words: Caatinga, Fabaceae, flora, plant taxonomy, unit of conservation.

\section{Introdução}

A Caatinga é um domínio fitogeográfico exclusivamente brasileiro, composto por um mosaico de florestas secas e vegetação arbustiva (savana-estépica), com enclaves de florestas úmidas montanas e de cerrados (Tabarelli \& Silva 2002). De acordo com o BFG (2018), a Caatinga possui cerca de 4.650 espécies vegetais, das quais 913 são endêmicas.
A alta diversidade biológica do município de Serra Talhada (MMA 2002) motivou a criação, em 2012, da primeira unidade de conservação do estado de Pernambuco em área de Caatinga, o Parque Estadual Mata da Pimenteira (PEMP) (Decreto Estadual $n^{\circ} 37.823$ ). O PEMP foi criado com o objetivo de conservar e de restaurar a diversidade ecológica na região, de forma a ampliar a representatividade dos ecossistemas presentes em Pernambuco em áreas de preservação.

\footnotetext{
${ }^{1}$ Universidade do Estado da Bahia - Campus VIII, Depto. Educação, Prog. Pós-graduação em Biodiversidade Vegetal, R. do Gangorra 503, Alves de Souza, 48608-240, Paulo Afonso, BA, Brasil.

${ }^{2}$ Universidade Federal Rural de Pernambuco, Unidade Acadêmica de Serra Talhada, Fazenda Saco, s.n., C.P. 063, 56900-000, Serra Talhada, PE, Brasil.

${ }^{3}$ Autor para correspondência: jussilva@uneb.br
} 
Leguminosae Adans., a mais diversa família de plantas da Caatinga, com aproximadamente 616 espécies e 128 gêneros (BFG 2018; Flora do Brasil 2020 em construção), é também a terceira maior família de angiospermas, com aproximadamente 750 gêneros e 19.500 espécies (Lewis et al. 2005). Tradicionalmente as espécies de Leguminosae estavam subordinadas a três subfamílias, Caesalpinioideae DC., Mimosoideae DC. e Papilionoideae DC. (Polhill et al. 1981). Entretanto, estudos moleculares verificaram que a subfamília Caesalpinioideae era polifilética (e.g., Chappill 1995; Doyle et al. 2000; Persson 2001; Wojciechowski et al. 2004; LPWG 2013). Desta forma, um novo arranjo para Leguminosae com seis subfamílias foi proposto: Cercidoideae LPWG, Detarioideae Burmeist. emend. LPWG, Duparquetioideae LPWG, Dialioideae LPWG, Papilionoideae e Caesalpinioideae DC. emend. LPWG (LPWG 2017).

O clado Mimosoide (mesmos representantes da antiga subfamília Mimosoideae) está inserido na subfamília Caesalpinioideae e apresenta cerca de 80 gêneros e 3.200 espécies distribuídas nas regiões tropicais, subtropicais e temperadas do globo. Caracteriza-se por apresentar folhas bipinadas (exceto Inga Mill., com folhas pinadas), flores agrupadas em glomérulos ou espigas, terminais ou axilares, corola com prefloração valvar (exceto Parkia R. Br.), estames vistosos e sementes com pleurograma (Lewis et al. 2005; LPGW 2017).

Sobre o conhecimento do clado Mimosoide na Caatinga, uma obra significativa para identificação dos táxons é Leguminosas da Caatinga onde foram identificados 22 gêneros e 95 espécies do clado Mimosoide, demonstrando assim a sua alta representatividade neste domínio (Queiroz 2009). Em Pernambuco, apenas os trabalhos de Ducke (1953) e Córdula et al. (2008) analisaram a família Leguminosae como um todo. No primeiro, 14 gêneros e 64 espécies pertencem ao clado Mimosoide, e no segundo estudo, 13 gêneros e 23 espécies.

Considerando que a família Leguminosae é a mais representativa na área, que os estudos florístico-taxonômicos no local são incipientes, e que a realização desse trabalho pode auxiliar no plano de manejo do PEMP, este trabalho visou realizar um tratamento taxonômico do clado Mimosoide no PEMP, apresentando chaves para identificação dos táxons e informações sobre a sua distribuição geográfica e período de floração e frutificação.

\section{Material e Métodos}

Área de estudo

O PEMP está localizado no município de Serra Talhada (753'49"'S e $\left.38^{\circ} 18^{\prime} 14^{\prime \prime} \mathrm{W}\right)$, semiárido de Pernambuco e ocupa 887,24 ha (Santos et al. 2013) (Fig. 1). O clima é quente e seco do tipo BSwh' (Köppen 1948), a temperatura média é de 23,8 $\pm 0,92{ }^{\circ} \mathrm{C}$ e apresenta baixo nível pluviométrico anual $(653,2 \mathrm{~mm})$. A altitude varia de $500-820 \mathrm{~m}$ e as principais classes de solos são os cambissolos, litólicos e podzólicos (Silva \& Almeida 2013). A vegetação é composta por caatinga, que varia de herbácea, arbustiva-arbórea até arbórea, sobre afloramentos rochosos (Melo et al. 2013).

\section{Tratamento taxonômico}

Para a realização deste estudo foi analisado espécimes pertencentes ao acervo dos herbários HESBRA, PEUFR, UFP, IPA acrônimo de acordo com Thiers (continuamente atualizado), bem como novos espécimes coletados durante esta pesquisa. Representantes do clado Mimosoide foram coletados mensalmente no período de março de 2015 a março de 2016 em diferentes ambientes do PEMP e na sua zona de amortecimento, segundo a metodologia sugerida por Mori et al. (1989). Todas as espécies coletadas foram fotografadas e amostras de flores, inflorescências e frutos foram armazenadas em recipiente com álcool etílico a $70 \%$ para os estudos morfológicos, descrições e ilustrações. Todo o material foi depositado no HESBRA e duplicatas foram doadas ao herbário HUNEB.

A identidade das espécies foi verificada através de obras clássicas e revisões (e.g., Barneby 1991; Lewis 1987), diagnoses originais e por comparação com imagens de coleções-tipo disponíveis na internet (site do NY, P, MO e K). Para as descrições seguiu-se as terminologias de Radford et al. (1974), Simpson (2006) e referências específicas em Leguminosae (Bentham 1870; Lewis 1987; Queiroz 2009) e, para determinar a forma dos nectários, foi utilizado Melo et al. (2010) e dos frutos Barroso et al. (1999). Os comentários sobre distribuição geográfica geral dos táxons foram baseados na literatura e no site da Flora do Brasil 2020 em construção (<http://floradobrasil. jbrj.gov.br/>), enquanto a ocorrência das espécies no PEMP foi determinada através de observações nas trilhas percorridas e análise das etiquetas dos espécimes analisados, onde também se verificou os dados do período de floração e frutificação. 


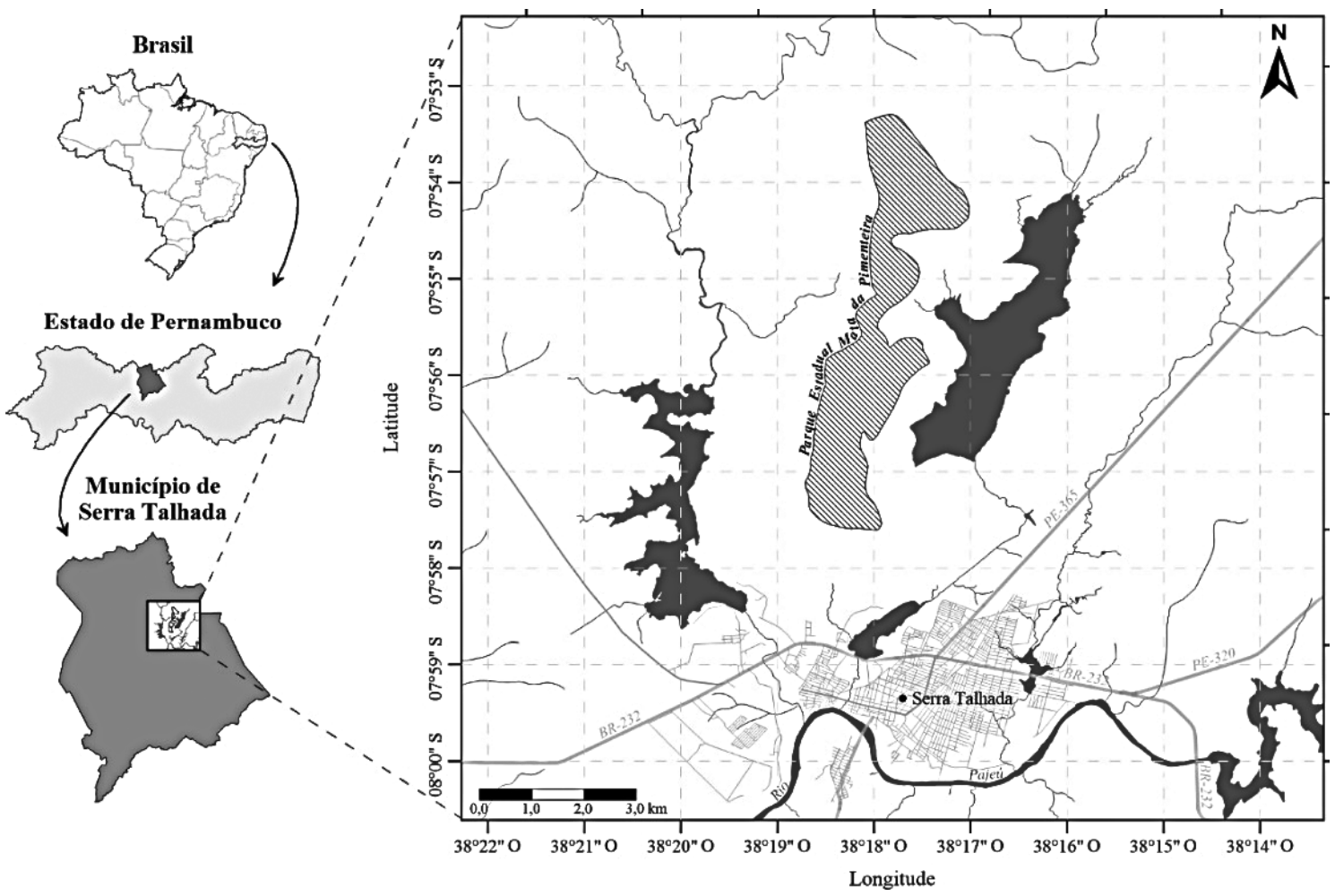

Figura 1 - Localização do Parque Estadual Mata da Pimenteira, Serra Talhada, Pernambuco. Figura 1 - Location of State Park Pimenteira Forest, Serra Talhada, Pernambuco.

\section{Resultados e Discussão}

O clado Mimosoide está representado no Parque Estadual Mata da Pimenteira por 14 espécies pertencentes a nove gêneros. Mimosa L., com seis espécies, foi o gênero mais representativo, enquanto os demais, Anadenanthera Speg., Chloroleucon (Benth.) Britton \& Rose, Desmanthus Willd., Enterolobium Mart., Neptunia Lour., Parapiptadenia Brenan, Piptadenia Benth. e Senegalia Raf., foram representados por uma espécie cada. A maioria dos representantes de Mimosoide tem ampla distribuição no Parque, entretanto, Enterolobium timbouva Mart., Chloroleucon dumosum (Benth.) G.P. Lewis e M. modesta var. ursinoides (Harms) Barneby foram observadas em áreas mais preservadas ou em pequenas populações. Neptunia plena (L.) Benth. foi observada exclusivamente associada a corpos d'água.
As espécies registradas ocorrem nos domínios fitogeográficos do Cerrado e da Mata Atlântica, com exceção de Mimosa modesta Mart., Parapiptadenia zehntneri (Harms) M. P. Lima \& H. C. Lima e Piptadenia stipulacea (Benth.) Ducke, que são endêmicas da Caatinga.

Considerando a lista preliminar de espécies contida no trabalho de Melo et al. (2013), neste estudo foram registrados seis novas ocorrência para o PEMP: Chloroleucon dumosum, Desmanthus pernambucanus (L.) Thell., Enterolobium timbouva Mart., Mimosa pigra L. var. pigra, Neptunia plena e Senegalia tenuifolia (L.) Britton \& Rose, das quais duas são endêmicas do Brasil.

Os principais caracteres diagnósticos para a distinção dos táxons são o número de folíolos, forma e localização de nectários, tipo de inflorescência, dimorfismo floral, morfologia dos frutos e sementes. 


\section{Chave de identificação para as espécies do clado Mimosoide do Parque Estadual Mata da Pimenteira, Serra Talhada, Pernambuco}

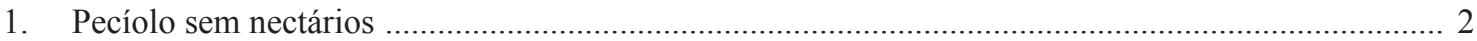

2. Inflorescência em espiga cilíndrica; filetes brancos ............................................................... 3

3. Foliólulos com pontuações glandulares na face abaxial; inflorescências latentes simultaneamente com as espigas expandidas ou até mesmo com infrutescências; cálice 4-angulado; frutos com artículos inflados na região das sementes 5.6 Mimosa tenuiflora

3'. Foliólulos sem pontuações glandulares na face abaxial; inflorescências latentes ausentes; cálice campanulado; frutos plano-compressos

4. Arbustos a árvores com 2-7 m alt.; 2-5 pares de folíolos; corola tubulosa, 4-angulada; fruto séssil 5.4 Mimosa ophthalmocentra

4'. Arbustos com 1,5-2,5 m alt.; 5-10 pares de folíolos; corola campanulada; fruto estipitado 5.1 Mimosa. arenosa var. arenosa

2'. Inflorescência em espiga globosa; filetes róseos

5. Arbustos; ramos, folhas e frutos hirsutos ferrugíneos; craspédios com 7-20 artículos 5.5 Mimosa. pigra var. pigra

5'. Subarbustos decumbentes; ramos, folhas e frutos pubescentes; craspédios não articulados ou com 3 artículos

6. Ramos com acúleos nodais; foliólulos 10; lâmina foliar elíptica (5-8 mm larg.); craspédios oblongos, com 3 artículos $(1,5-2,3 \times 0,8-1 \mathrm{~cm})$.... 5.3 Mimosa modesta var. ursinoides

6'. Ramos com acúleos dispostos em fileiras longitudinais sobre as costelas; foliólulos 14-28; lâmina foliar oblonga (1-3 mm larg.); craspédios lineares não articulados (6-10 $\times 0,2-0,4 \mathrm{~cm})$ 5.2 Mimosa candollei

1'. Pecíolo com nectários 7

7. Raque sem nectários 8

8. Ramos aculeados; nectário elíptico; espigas cilíndricas; legumes estipitados, oblongos ...... 8. Piptadenia stipulacea

8'. Ramos inermes; nectário orbicular; espigas globosas; legumes sésseis, lineares

3. Desmanthus pernambucanus

7'. Raque com nectários entre o primeiro par ou nos pares distais de folíolos 9

9. Espiga cilíndrica; corola e filetes vermelho-escuro; sementes aladas

7. Parapiptadenia zehntneri

9'. Espiga globosa a subglobosa; pétalas e filetes brancos, cremes ou verdes; sementes não aladas 10

10. Lâmina foliar 3-9 mm larg.; legume bacoide, reniforme ... 4. Enterolobium timbouva 10'. Lâmina foliar $<2,5 \mathrm{~mm}$ larg.; folículos ou legume 11

11. Erva prostrada; ramo esponjoso; espiga globosa heteromórfica; flores centrais andróginas, marginais estéreis; estaminódios estreitamente elípticos, laminares, amarelo-ouro 6. Neptunia plena

11'. Árvore ou arbusto; caule lenhoso; glomérulo homomórfico; flores todas andróginas; estaminódios ausentes

12. Nectário orbicular; glomérulo obcônico, elevado-cônico

2. Chloroleucon dumosum

12'. Nectário elipsoide a oblongo ou cônico; glomérulo globoso 13

13. Nectário na região mediana do pecíolo, elipsoide a oblongo; foliólulos 70-140; estames 8; fruto folículo 1. Anadenanthera colubrina

13'. Nectário abaixo da região mediana do pecíolo, cônico; foliólulos 34-60; estames $80-85$, fruto legume 9. Senegalia tenuifolia 
1. Anadenanthera Speg., Physis (Buenos Aires) 6: 313, 1923.

Gênero circunscrito a duas espécies, Anadenanthera colubrina (Vell.) Brenan e $A$. peregrina (L.) Speg., que ocorrem nas Antilhas, Argentina, Bolívia, Brasil, Paraguai e Peru (Altschul 1964; Luckow 2005). As duas espécies são encontradas no Brasil nos domínios fitogeográficos da Amazônia, Caatinga, Cerrado, Mata Atlântica e apenas A. colubrina ocorre no PEMP.

1.1 Anadenanthera colubrina (Vell.) Brenan, Kew Bull. 10(2): 182. 1955.

Fig. 2a-b

Árvore $6 \mathrm{~m}$ alt.; ramos marrom-escuros, cilíndricos, aculeados, puberulentos, indumento esbranquiçado, ramos jovens inermes. Acúleos cônicos, retos, densos; lenticelas elípticas a circulares, cremes, adensadas. Gemas protegidas por catafilos imbricados, inconspícuos. Estípulas caducas, 6-7 × 1-1,5 mm, lineares, assimétricas, puberulentas. Folhas com 2-11 pares de folíolos; pecíolo 1,5-4 cm compr., pubescente, nectário 1, na região mediana do pecíolo, elipsoide a oblongo, elevado plano, sem espículas; raque $3-14 \mathrm{~cm}$ compr., pubescente, nectário 0-6, entre os pares de folíolos distais, elipsoides, elevado plano; foliólulos 70-140; ráquila $1,5-5,5 \mathrm{~cm}$ compr., sulcada, sem parafilídios; lâmina 1,5-4 ×0,4-0,8 $\mathrm{mm}$, estreitamente oblonga a estreitamente elíptica, base oblíqua, ápice agudo, margem ciliada, glabra, sem pontuações, nervura principal subcêntrica, secundárias inconspícuas. Pedúnculo $3-30 \mathrm{~cm}$ compr., pubescente; bráctea $1-1,5 \times 0,25-0,5$ $\mathrm{mm}$, elíptica-oblanceolada, pubescente; bractéola ausente. Espiga globosa, homomórfica, 1-3,5 cm compr., terminal. Flores andrógenas, pentâmeras, sésseis; cálice 1,5-2 × 1-1,5 mm, campanulado, puberulento, lobos triangulares; corola $2-3 \times$ 0,5-1 mm, campanulada, glabra, branca, lobos triangulares; estames 10 , filetes ca. $8 \mathrm{~mm}$ compr., brancos, antera globosa, glândula apical presente; ovário elíptico, óvulo por lóculo 16; estilete reto, 4-6 mm compr., estigma filiforme, estaminódios ausentes. Folículos 10-30 × 0,5-2 cm, estipitados, lineares, margem sinuosa, glabros, castanhos; estípite 1-6 cm compr.. Sementes 10-12,5 × 9-11 $\mathrm{mm}$, oblongas a orbiculares, não aladas, planocompressas, marrons.

Material examinado: Serra Talhada, Campus UAST, 30.XI.2015, fl. e fr., S.S. Matos et al. 820 (HESBRA); Estação da UFRPE, 8.VI.2005, fr., L.M. Pessoa 270 (PEUFR); Estação Experimental do IPA - Lauro Bezerra, 2010.1, fr., Y.H. Leal et al. 3 (HESBRA).
Material adicional: BRASIL. PERNAMBUCO: Santa Cruz da Baixa Verde, Olho d'Água, Serra da Madeira, 21.II.2013, fr., A.F. Silva 2 (HESBRA).

Nome popular: Angico.

Espécie sulamericana, ocorrendo no Peru, Brasil e Argentina (Altschul 1964). No Brasil, tem ampla distribuição, ocorrendo no Nordeste (BA, CE, PB, PE, PI, RN, SE), Centro-Oeste (DF, GO, MS, MT), Sudeste (MG, RJ, SP) e Sul (PR), nos domínios fitogeográficos da Caatinga, Cerrado e Mata Atlântica (Morim 2018a). Frequente e de ampla distribuição no PEMP, Anadenanthera colubrina é observada em locais preservados e perturbados, planos e nas vertentes da Serra Talhada. Muitas vezes sobressai-se no dossel da caatinga como uma árvore emergente, mas também é encontrada isolada em áreas degradadas. Floresce e frutifica de maio a agosto.

Anadenanthera colubrina distingue-se das demais espécies de Mimosoide do PEMP por apresentar foliólulos pequenos 1,5-4 × 0,4-0,8 mm (vs. 1-31 mm) e numerosos 70-140 (vs. 4-90) e frutos tipo folículo maiores que os demais 10-30 $\mathrm{cm}(v s .3-10 \mathrm{~cm})$.

Ilustrações: Queiroz (2009).

2. Chloroleucon (Benth.) Britton \& Rose, Trop. Woods 10: 24.1927.

Chloroleucon é um gênero com 10 espécies, presentes no México, Antilhas, Brasil e Argentina (Lewis et al. 2005). No Brasil, são reconhecidas sete espécies distribuídas nos domínios fitogeográficos da Amazônia, Caatinga, Cerrado, Mata Atlântica e Pantanal (Souza 2018). Apenas Chloroleucon dumosum (Benth.) G.P. Lewis foi registrada para $\mathrm{a}$ área de estudo.

2.1 Chloroleucon dumosum (Benth.) G.P. Lewis, Legumes of Bahia 165. 1987.

Fig. 2c

Arbusto 3-4 m alt.; ramos marrons, cilíndricos, glabros, espinescentes. Espinhos nodais, retos, geralmente aos pares, base estreita; lenticelas lineares a circulares, cremes, esparsas. Gemas protegidas por catáfilos imbricados, deltoides. Estípulas caducas, ca. 3,5 × 0,3 mm, lineares, puberulentas. Folhas com 5-6 pares de folíolos; pecíolo 1-1,5 cm compr., pubescente, nectário 1, abaixo da região mediana do pecíolo, orbicular, elevado-côncavo, sem espículas; raque 0,8-3,5 cm compr., pilosa, inerme, nectários $1-3$, nos pares de folíolos distais, orbiculares, elevado-côncavo; foliólulos 18-42; ráquila $1-3 \mathrm{~cm}$ compr., cilíndrica a subcilíndrica, sem parafilídios; 

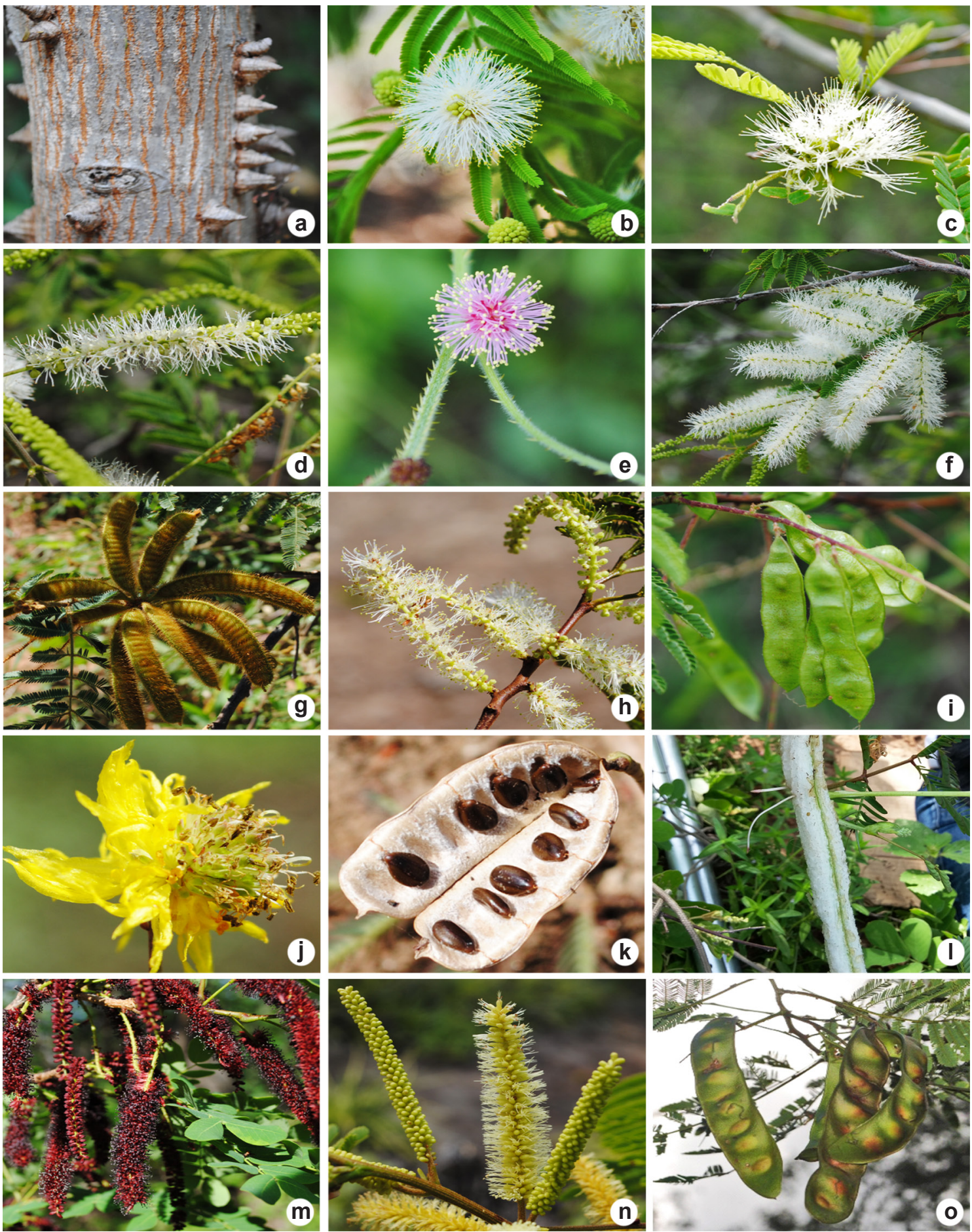

Figura 2 - Clado Mimosoide no Parque Estadual Mata da Pimenteira, semiárido de Pernambuco, Brasil - a-b. Anadenanthera colubrina. c. Chloroleucon foliolosum. d. Mimosa arenosa var. arenosa. e. Mimosa candollei. f. Mimosa ophthalmocentra. g. Mimosa pigra L. var. pigra. h-i. Mimosa tenuiflora. j-1. Neptunia plena - caule. m. Parapiptadenia zehntneri. n-o. Piptadenia stipulacea. Fotos: A. Laurênio.

Figure 2 - Mimosoid Clade in the Mata da Pimenteira State Park, Semiarid of Pernambuco, Brazil - a-b. Anadenanthera colubrina. c. Chloroleucon foliolosum. d. Mimosa arenosa var. arenosa. e. Mimosa candollei. f. Mimosa ophthalmocentra. g. Mimosa pigra L. var. pigra. h-i. Mimosa tenuiflora. j-1. Neptunia plena. m. Parapiptadenia zehntneri. n-o. Piptadenia stipulacea. Fotos: A. Laurênio. 
lâmina 3-5 × 1-1,5 mm, estreitamente elíptica, base oblíqua, ápice arredondado, margem ciliada, face adaxial glabra a pubescente, face abaxial pubescente, sem pontuações, nervura principal subcêntrica, secundárias conspícuas em ambas as faces ou inconspícuas na face abaxial. Pedúnculo 10-15 mm compr., pubescente; bráctea ausente; bractéola $0,2-0,3 \mathrm{~mm}$, estreitamente triangular, pubescente. Espiga globosa, homomórfica, 1,5-2 cm diâm., axilar, obcônico. Flores andróginas, pentâmeras, sésseis; cálice 1,5-2 × 0,5-1 mm, tubular, glabro, lobos triangulares; corola 4-5 × 1-2 $\mathrm{mm}$, tubular, glabra, verde-claro, lobos triangulares; estames ca. 11, monadelfos, filetes ca. $6 \mathrm{~mm}$ compr., brancos, antera globosa sem glândulas apicais; ovário elíptico, óvulo por lóculo 7; estilete reto, $3 \mathrm{~mm}$ compr., estigma filiforme, estaminódios ausentes. Folículos 4-12 × 1,2-1,8 cm, oblongos, margem sinuosa, glabros, castanhos; estípite 0,5-2 cm compr.. Sementes 7-7,5 ×5 mm, elípticas, não aladas, plano-compressas, marrons amarelados.

Material examinado: Serra Talhada, Estação Experimental do IPA, 29.VIII.1995, fr., M.L. Gomes et al. 99 (IPA); Estação Experimental do IPA - Lauro Bezerra, 2010, fr., J.F. Santos 5 (HESBRA); Serra Branca, 3.VI.2010, fr., R.S. Cordeiro et al. 109 (HESBRA); 12.XI.2010, fl., R.S. Cordeiro 152 (HESBRA). Serra Talhada, Arredores do Campus da UAST, 2010, fr., M.E.O. Barbosa 3 (HESBRA).

Material adicional: BRASIL. PERNAMBUCO: Águas Belas, mata próxima a Aldeia Ouricuri, Terra Indígena Fulni-ô, 15.VII.2007, fr., G.T. Soldati et al. 14 (PEUFR); Mata do Paredão (Aldeia Sede Fulni-ô), 14.II.2008, fl., G.T. Soldati et al. 186 (PEUFR). Altinho, Comunidade de Carão 24.VIII.2007, fr., L.L. Santos et al. 305 (PEUFR). Ibimirim, estrada Ibimirim-Petrolândia, 11.XII.1995, fl., $A$. Laurênio et al. 296 (PEUFR). Ipojuca, Arcoverde, Fazenda Cavalcanti, 24.I.2010, fl., M.D. Barbosa 39 (PEUFR).

Chloroleucon dumosum é endêmica do Brasil distribuída nas regiões: Nordeste (AL, BA, CE, PB, PE, PI, RN, SE), Centro-Oeste (DF) e Sudeste (MG, RJ), presente nos domínios fitogeográficos da Caatinga, Cerrado e Mata Atlântica (Souza 2018). Ocorre ocasionalmente no PEMP, tanto em áreas baixas e planas, quanto nas vertentes e no topo da Serra Talhada, às vezes, associada a afloramentos rochosos. Floresce em novembro e frutifica em julho e agosto.

Chloroleucon dumosum é facilmente reconhecida pelos espinhos nodais retos, geralmente aos pares, nectários na região mediana do pecíolo, orbicular, elevado côncavo e pelo glomérulo obcônico axilar.

Ilustrações: Queiroz (2009).
3. Desmanthus Willd., Sp. Pl. 4(2): 888, 10441049, 1806.

Gênero nativo da região Neotropical com 24 espécies, concentradas principalmente no México e sul dos Estados Unidos (Luckow 1993). Para o Brasil são referidas cinco espécies distribuídas, sobretudo, em áreas de Caatinga e Cerrado (BFG 2018). Apenas Desmanthus pernambucanus foi encontrada no PEMP.

3.1 Desmanthus pernambucanus (L.) Thell., Fl. Adv. Montpellier 296. 1912.

Subarbusto $50-70 \mathrm{~cm}$ alt.; ramos verdes com estrias avermelhadas, cilíndricos, glabros. Gemas sem catáfilos. Estípulas persistentes, 4-7 $\times 0,25-0,5 \mathrm{~mm}$, triangulares, auriculadas, glabras a puberulentas. Folhas 2-8 pares de folíolos; pecíolo 0,7-3,5 cm compr., glabro, nectário 1, entre o primeiro par de folíolos, elipsoide a orbicular, elevado-côncavo, sem espículas; raque 8-21 cm compr., glabra, sem nectários; foliólulos 18-60; ráquila 0,5-5,5 cm compr., sulcada, sem parafilídios; lâmina 2-6 × 0,5-1 $\mathrm{mm}$, estreitamente oblonga, base oblíqua, ápice cuspidado, margem ciliada, glabra em ambas as faces, sem pontuações, nervura principal subcêntrica, secundárias inconspícuas em ambas as faces. Pedúnculo 4-25 mm compr., glabro; bráctea $1-3 \times 0,5$, triangular, glabra a raro pubescente, bractéola 1-2,5 × 0,5-0,8 mm, trulada, pubérulo. Espiga globosa, heteromórfica, 0,5-2,5 cm diâm., obcônico, axilar. Flores estaminadas centrais, andróginas marginais ou centrais, pentâmeras, sésseis; cálice 1,5-2,5 × 1,5-2 mm, tubular, glabro, lobos triangulares; corola 4-8 $\times 0,5-1 \mathrm{~mm}$, tubular, glabra, verde-claro, lobos triangulares; estames 10 , filetes ca. 5-7 mm compr., brancos, antera globosa sem glândulas apicais; ovário elíptico, óvulo por lóculo 18-32; estilete fortemente sinuoso, 8,5 mm compr., estigma truncado. Legumes 4,5-9 $\times$ 0,4-0,5 cm, sésseis, lineares, margem reta, glabros, castanhos. Sementes 2,5-3 × 2-3 mm, circulares, marrons, não aladas, plano-compressas.

Material examinado: Serra Talhada, campus da UAST, 22.I.2016, fr., S.S. Matos et al. 851 (HESBRA).

Material adicional: BRASIL. PERNAMBUCO: Cabrobó, Mãe Rosa. Eixo Norte-Projeto de Integração do rio São Francisco, 19.VII.2007, fl., M. Oliveira et al. 2977 (UFP); Venturosa, Parque Municipal da Pedra Furada, 1.VII.2007. fl., Y. Melo et al. 265 (UFP).

Espécie que ocorre na maioria das ilhas do Caribe, no Brasil e Uruguai. Foi introduzida e tornou-se invasora nas ilhas dos oceanos Pacífico e 
Índico, no sul da África e sudeste da Ásia (Queiroz 2009). No Brasil, distribui-se no Nordeste (BA, MA, PB, PE, PI), Centro-Oeste (MS) e Sudeste (RJ), nos domínios fitogeográficos da Caatinga e Mata Atlântica (BFG 2018). É encontrada em áreas degradadas, plantações e margens de estradas. Floresce e frutifica em janeiro.

Desmanthus pernambucanus destaca-se na área de estudo pelo hábito subarbustivo, glomérulo heteromórfico, obcônico, corola e filetes brancos, estigma truncado e fruto do tipo legume, linear. Compartilha com Neptunia plena o glomérulo heteromórfico, mas estas espécies não são confundidas, pois, a última apresenta hábito herbáceo prostrado, flores predominantemente amarelas e fruto do tipo folículo, oblongo.

A presença de flores andróginas, estaminadas e estéreis em uma mesma inflorescência em $D$. pernambucanus é relatada por Queiroz (2009), entretanto não foram encontradas flores estéreis nos espécimes examinados do PEMP.

Ilustrações: Queiroz (2009).

4. Enterolobium Mart., Flora 20 (2, Beibl.): 116, 1837.

Gênero com 11 espécies, distribuídas no México, América Central e América do Sul. As espécies sul-americanas ocorrem na Argentina, Bolívia, Brasil, Colômbia, Paraguai, Uruguai, Venezuela (Lewis et al. 2005). No Brasil, são registradas nove espécies presentes nos domínios da Amazônia, Caatinga, Cerrado, Mata Atlântica, Pantanal (Morim et al. 2018). No PEMP, foi encontrada Enterolobium timbouva Mart.

4.1 Enterolobium timbouva Mart., Flora 20(2): Beibl. 128. 1837.

Árvore, 10-15 m alt.; ramos castanhos a acizentados, cilíndricos, inermes, glabros ou pubérulos, indumento esbranquiçado; lenticelas elípticas a circulares, cremes, esparsas. Gemas sem catáfilos. Estípulas caducas, $1-2 \times 0,3-0,4$ $\mathrm{mm}$, triangulares, glabrescentes. Folhas $2-3$ pares de folíolos; pecíolo 3-5 cm compr., tomentoso, nectário 1 , abaixo da região mediana do pecíolo, na região mediana do pecíolo, ou próximo ao primeiro par de pina, elipsoide, elevado plano; raque $1,5-8,5 \mathrm{~cm}$ compr., tomentoso, nectário nos pares de folíolos distais, $2-5$, orbicular, elevado plano; foliólulos $12-28$; ráquila $5-8,7 \mathrm{~cm}$ compr., cilíndrica a subcilíndrica, parafilídios subulados, acima do pulvino da pina; lâmina 5-31 × 2-9 mm, estreitamente elíptica, base oblíqua, ápice agudo, margem ciliada, em ambas as faces raro pubescente a glabra, sem pontuações, nervura principal excêntrica, secundárias conspícuas em ambas as faces. Pedúnculo 11-22 mm compr., tomentoso; bráctea ausente; bractéola $1,5 \times 0,5 \mathrm{~mm}$, triangular, tomentosa. Espiga subglobosa, homomórfica, 2,5-4 cm diâm., axilar. Flores andróginas, pentâmeras, sésseis; cálice 1-2 × 1,5-2 mm, tubular, piloso, lobos triangulares; corola 4-6 $\times 1-2 \mathrm{~mm}$, tubular, glabra, branca, lobos triangulares; estames $54-70$, filetes ca. 5-6 mm compr., brancos, antera globosa sem glândulas apicais; ovário elíptico, óvulo por lóculo, estilete $1 \mathrm{~mm}$ compr., estigma filiforme, $1 \mathrm{~mm}$ compr. Legumes bacoides, 7-9,5 × 8-10,5 cm, não articulados, estipitados, reniformes, margem sinuosa, glabros, enegrecidos; estípite $3-5,5 \mathrm{~cm}$ compr.. Sementes 15-17 × 9-11 mm, elípticas a ovais, não aladas, não plano-compressas, marrom claras.

Material examinado: Serra Talhada, campus da UAST, 30.XI.2015, fl. e fr., S.S. Matos et al. 831 (HESBRA).

Material adicional: BRASIL. PERNAMBUCO: Santa Cruz da Baixa Verde, Olho d'Água, Serra da Madeira, 22.II.2013, fr., M. Barboza 2 (HESBRA); 25.VII.2013, fr., M.R.L. Nogueira 1 (HESBRA).

Nome popular: tamboril.

Espécie ocorre amplamente na América do Sul (Mesquita 1990). Em território brasileiro é encontrada no Norte (PA), Nordeste (BA, CE, MA, PB, PE, PI, SE), Centro-Oeste (DF, GO, MS) e Sudeste (MG, SP) e está presente nos domínios fitogeográficos da Amazônia, Caatinga, Cerrado, Mata Atlântica e Pantanal (Morim et al. 2018). No PEMP, apenas poucos indivíduos desta espécie foram encontrados em áreas de cultivo abandonadas. Floresce e frutifica em junho.

Enterolobium timbouva é facilmente identificada por ser uma árvore de grande porte (10-15 m alt.), com folíolos relativamente grandes (5-31 × 2-9 mm), espigas subglobosas, estames numerosos (ca. 54-70) e o fruto do tipo legume bacoide, reniforme 7-9,5 × 8-10,5 cm, não planocompresso. Além disso, as estípulas desta espécie são precocemente caducas e não deixam cicatrizes. Ilustrações: Queiroz (2009).

\section{Mimosa L., Sp. Pl. 1: 516, 1753.}

Mimosa compreende cerca de 540 espécies, principalmente, americanas, mas também ocorrendo na África e Ásia (Barneby 1991; Simon et al. 2011). No Brasil, é um gênero bem representativo, com 359 representantes, que ocorrem nos domínios fitogeográficos da Amazônia, Caatinga, Cerrado, Mata Atlântica, Pampa e Pantanal (BFG 2018). 
$\mathrm{Na}$ área de estudo foram observadas seis espécies, Mimosa arenosa (Willd.) Poir., M. candollei R. Grether, M. modesta var. ursinoides, $M$. ophthalmocentra Mart. ex Benth., M. pigra var. pigra e M. tenuiflora (Willd.) Poir.

5.1 Mimosa arenosa (Willd.) Poir. var. arenosa, Encycl., Suppl. 1(1): 66. 1810.

Fig. 2d

Arbusto 1,5-2,5 m alt.; ramos marrons, cilíndricos, aculeados ou inermes, tomentosos, indumento esbranquiçado. Acúleos esparsos, internodais, ligeiramente incurvados, base alargada; lenticelas lineares a circulares, cremes, adensadas. Gemas protegidas por catáfilos imbricados, estreitamente triangulares. Estípulas persistentes, 2-4 $\times 0,25-1 \mathrm{~mm}$, triangulares, tomentosas. Folhas 5-10 pares de folíolos; pecíolo 1-2,2 cm compr., tomentoso, sem nectário; espículas subuladas entre cada par de folíolos; raque 2-12 cm compr., tomentoso, sem nectários, foliólulos 18-40; ráquila 2-4,5 cm compr., angulosa, parafilídios subulados; lâmina 2-6 × 1-1,25 mm, estreitamente oblonga, base oblíqua, ápice redondo-apiculado, margem ciliada, pubescente, nervura principal excêntrica, secundárias pouco conspícuas na face abaxial e inconspícuas na face adaxial. Pedúnculo 0,5-1,5 cm compr., tomentoso; bráctea $2-5 \times 0,5-1 \mathrm{~mm}$, triangular, tomentosa; bractéola $1-1,5 \times 0,25-0,5$ $\mathrm{mm}$, trulada, tomentosa. Espiga cilíndrica 3,5-6 cm compr., axilar. Flores andróginas, tetrâmeras, sésseis; cálice 0,5-1 × 0,5-1 mm, campanulado, glabro a pubescente, lobos triangulares; corola 2,5-3 × 2-3 mm, campanulada, glabra a raro pubescente, branca, lobos triangulares; estames 7-8, filetes 7-8, 5-8 mm compr., brancos, antera globosa sem glândulas apicais; ovário elíptico, óvulo por lóculo 5; estilete $1 \mathrm{~mm}$ compr., estigma filiforme. Craspédios 1,5-5,5 × 0,4-0,7 cm, 4-8 artículos, estipitados, plano-compressos, estreitamente oblongos com ou sem constrições, margem reta, glabros, marrons; estípite 0,6-1 cm compr. Sementes 2-3,5 × 2-3 mm, largamente ovais, verdes a castanhos, não aladas, planocompressas.

Material examinado: Serra Talhada, Estação Experimental do IPA, V.1991, fl., R. Pereira 53855 (IPA); 2010, fl. e fr., J.F. Santos 2 (HESBRA); Serra Branca, 26.VIII.2009, fr., T.B. Amorim s.n. (HESBRA 1548); 24.V.2011, fl., T.A. Magalhães 2 (HESBRA); 24.V.2011, fl. e fr., A.T.S. Oliveira 1 (HESBRA); Parque Estadual Mata da Pimenteira, próximo ao Açudezinho, 9.VI.2016, fr., J.F.N. Araújo 1 (HESBRA); topo da Serra Talhada, próximo às antenas, 2.VI.2016, fl., D.M. Souza 1 (HESBRA).
Material adicional: BRASIL. PERNAMBUCO: Triunfo, mata do Brejinho, 15.III.2014, fl., L. MacielJúnior 203 (HESBRA); mata próxima ao SESC, 17.VII.2014, fr., J.R.S. Freire 3 (HESBRA); 17.VII.2014, fl. e fr., S.E.A. Marques 2 (HESBRA).

Nome popular: Jureminha.

Esta variedade é distribuída no Brasil, Porto Rico e costa da Venezuela (Barneby 1991; Santos-Silva et al. 2015). No Brasil é encontrada, principalmente, no Nordeste (BA, CE, PB, PE, PI, RN, SE), mas também no Sudeste (MG, SP). Ocorre nos domínios fitogeográficos da Caatinga, Cerrado e Mata Atlântica (BFG 2018). Forma pequena e difusa população no PEMP, encontrada em áreas planas e baixas (500 m alt.) até próximo ao topo da Serra Talhada (600-750 m), algumas vezes, em frestas de afloramentos rochosos. Floresce e frutifica praticamente o ano todo.

Entre as espécies encontradas no PEMP, $M$. arenosa assemelha-se morfologicamente a $M$. ophthalmocentra e $M$. tenuiflora por este grupo de espécies apresentarem inflorescências em espigas cilíndricas e filetes brancos. Distingue-se de $M$. ophthalmocentra pelos craspédios com estípites longos de 0,6-1 cm compr. (vs. estípite séssil em $M$. arenosa var. arenosa) e de $M$. tenuiflora pela ausência de pontuações glandulares na face abaxial dos foliólulos ( $v s$. foliólulos com pontuações glandulares).

Ilustrações: Dourado et al. (2013) e SantosSilva et al. (2015).

5.2 Mimosa candollei R. Grether, Novon 10(1): 34. 2000.

Fig. 2e

Mimosa quadrivalvis L., Sp. P1. 1: 522. 1753.

Schrankia leptocarpa DC., Prodr. 2: 443. 1825.

Mimosa quadrivalvis var. leptocarpa (DC.) Barneby, Mem. New York Bot. Gard. 65: 298. 1991.

Erva a subarbusto decumbente; ramos verdes, angulosos, aculeados, pubescentes, sem lenticelas. Acúleos recurvados, dispostos em fileiras longitudinais sobre as costelas, estendendo-se também no pecíolo; indumento esbranquiçado. Gemas protegidas por catáfilos imbricados, estreitamente triangulares a lineares. Estípulas persistentes, $1-8 \times 0,25-0,5 \mathrm{~mm}$, lanceoladas a lineares, pubescentes. Folhas $1-3$ pares de folíolos; pecíolo 0,7-7 cm compr., pubescente, sem nectário, espículas subuladas a lineares entre cada par de foliólulos; raque 1-4 cm compr., pubescente, sem nectários; foliólulos 14-28; ráquila $0,7-4 \mathrm{~cm}$ compr., parafilídios subulados; lâmina 2-12 × 1-3 $\mathrm{mm}$, estreitamente oblonga, base oblíqua, ápice 
obtuso a redondo apiculado, margem ciliada, raro pubescente a glabra em ambas as faces, nervura principal subcêntrica, secundárias inconspícuas a pouco conspícuas na face abaxial e inconspícuas na face adaxial. Pedúnculo 3-8 mm compr., piloso; bráctea $4-7 \times 0,25-0,5 \mathrm{~mm}$, lanceolada a linear, pubescente; bractéola $0,5-1,5 \times 0,25-0,5 \mathrm{~mm}$, estreitamente elíptica. Espiga globosa, $0,5-1 \mathrm{~cm}$ diâm., axilar. Flores todas andróginas, pentâmeras, sésseis; cálice $0,5 \times 0,5-1 \mathrm{~mm}$, campanulado, glabro, lobos triangulares; corola 2-3 $\times 1-2,5 \mathrm{~mm}$, campanulada, glabra, rósea, lobos triangulares; estames 9-10, filetes 3-5 mm compr., lilás, com anteras cor creme, antera globosa sem glândulas apicais; ovário elíptico, óvulo por lóculo 10, estilete $2 \mathrm{~mm}$ compr., estigma filiforme. Craspédios 6-10 $\times 0,2-0,4 \mathrm{~cm}$, não articulados, séssil a curtoestipitados, lineares, ápice espinescente, margem reta, pubescentes, castanhos; estípite ca. $0,1 \mathrm{~cm}$ compr.. Sementes ca. $2 \times 3 \mathrm{~mm}$, oblongas, verdes, não aladas, plano-compressas.

Material examinado: Serra Talhada, Campus UAST, 19.IV.2016, fl. e fr., S.S. Matos et al. 851 (HESBRA); 22.III.2010, fl., G.P. Silva 55 (HESBRA); Estação Experimental do IPA, 7.VII.2007, fr., Y. Melo et al. 283 (UFP); 9.VII.2008, fl., C. Ferreira 83861 (IPA); Lagoa Pimenteira II, 19.XI.2011, fl. e fr., W. Cordeiro 123 (HESBRA); PEMP, estrada de Varzinha a Caiçarinha da Penha, 26.III.2014, fr., L. Maciel-Júnior et al. 217 (HESBRA); topo da Serra Talhada, 2.VI.2016, fr., A.M.M. Boaventura 1 (HESBRA).

Nome popular: malícia.

Espécie distribuída nas Américas, desde o sul dos Estados Unidos até Argentina e Uruguai (Queiroz 2009). No Brasil é registrada para todos os estados, exceto Rio Grande do Sul, ocorrendo nos domínios fitogeográficos da Amazônia, Caatinga, Cerrado e Mata Atlântica (BFG 2018). Espécie de ampla distribuição no PEMP, observada, principalmente, próximo a corpos d'água e comumente em áreas perturbadas, sendo algumas vezes, invasores de cultivos, em solos argilo-arenosos ou compactados sobre afloramentos rochosos. Floresce e frutifica praticamente $\mathrm{o}$ ano inteiro.

Mimosa candollei é facilmente reconhecida por apresentar hábito herbáceo a subarbustivo decumbente, acúleos ao longo do ramo, estendendose para o pecíolo, raque, pelos folíolos estreitamente oblongos (1-3 mm larg.) e pelo craspédio não articulado linear aculeado.

Nos herbários visitados (IPA, PEUFR, UFP) estava na maioria das vezes identificada pelo seu sinônimo Schrankia leptocarpa DC.

Ilustrações: Peterle et al. (2015).
5.3 Mimosa modesta var. ursinoides (Harms) Barneby, Brittonia 37(2): 153. 1985.

Subarbusto decumbente $90 \mathrm{~cm}$ alt.; ramos marrons claros, cilíndricos, aculeados, pubescentes, indumento esbranquiçado. Acúleos nodais abaixo dos pecíolos e nos craspédios, ligeiramente incurvos, base ligeiramente alargada, sem lenticelas. Gemas protegidas por catáfilos imbricados, lineares. Estípulas persistentes, 6-8 $\times 0,5-1 \mathrm{~mm}$, triangulares, pubescentes. Folhas 1 par de folíolos; pecíolo 1-2 cm compr., viloso, sem nectário; foliólulos 10 ; ráquila $1,8-2,3 \mathrm{~cm}$ compr., parafilídios ausentes; lâmina 6-15 × 5-8 $\mathrm{mm}$, elíptica, base redonda a oblíqua, ápice redondo apiculado, margem ciliada, face abaxial pubescente, face adaxial glabra, nervuras. Pedúnculo ca. 23 $\mathrm{mm}$ compr., viloso; bráctea $7-8 \times 0,5-1 \mathrm{~mm}$, triangular, pubescente; bractéola $2-3 \times$ ca. $1 \mathrm{~mm}$, oblanceolada, setosa. Espiga globosa, 1,2-3 cm diâm., axilar. Flores todas andróginas, tetrâmeras, sésseis; cálice ca. $0,5 \times 0,5 \mathrm{~mm}$, campanulado, glabro, lobos triangulares; corola 1,5-3 $\times 0,5-1$ $\mathrm{mm}$, tubular, pubescente, rósea, lobos triangulares; estames 4, filetes 2-3 mm compr., cremes, antera globosa sem glândulas apicais; ovário elíptico, estipitado, óvulo por lóculo 4; estilete $1 \mathrm{~mm}$ compr., estigma filiforme. Craspédios 1,5-2,3 $\times 0,8-1 \mathrm{~cm}, 3$ artículos, estipitados, oblongos, ápice apiculado, margem sinuosa, pubescentes, castanhos; estípite $0,4-0,5 \mathrm{~cm}$. Sementes $4,5-5$ $\times$ 4-5 mm, largamente ovoides, não aladas, não plano-compressas, marrons.

Material examinado: Serra Talhada, PEMP, Lagoa Pimenteira III, 15.IV.2014, fl. e fr., S.S. Matos et al. 512 (HESBRA).

Material adicional: BRASIL. PERNAMBUCO: Buíque, Parque Nacional do Catimbau, 29.IX.2004, fl., R.A. Pick et al. 117 (UFP); Mirandiba, Malhada da Areia, 10.III.2008, fl., E. Córdula et al. 360 (UFP).

Espécie endêmica da Região Nordeste (BA, PE, PI, RN) do Brasil, nos domínios fitogeográficos da Caatinga e Cerrado. Esta variedade ocorre Nordeste (BA, PE, PI, RN) e está presente no domínio fitogeográfico da Caatinga (BFG 2018). No PEMP é rara, encontrada em locais mais preservados formando pequenas populações próximas a cursos d'água. Floresce e frutifica em abril.

Mimosa modesta var. ursinoides destaca-se no PEMP por ser um subarbusto decumbente, com acúleos nodais abaixo dos pecíolos e, também, nos craspédios, estes ligeiramente incurvos e com base alargada. Além disso, apresenta sempre um par de folíolos e craspédios com três artículos. M. modesta 
var. ursinoides compartilha com Mimosa candollei o hábito e, às vezes, a presença de um par de folíolos. Entretanto, a forma da lâmina foliar de $M$. modesta var. ursinoides é elíptica (vs. oblonga em M. candollei), e tem a largura de 5-8 mm (vs. 1-3 $\mathrm{mm}$ ) e os craspédios são oblongos, 3-articulados (vs. lineares não articulados).

Ilustrações: Queiroz (2009).

5.4 Mimosa ophthalmocentra Mart. ex Benth., Trans. Linn. Soc. London 30(3): 415. 1875.

Fig. $2 f$

Arbusto a árvore 2-7 m alt.; ramos marrons, estriados, puberulentos, inermes ou aculeados, indumento esbranquiçado. Acúleos raros, internodais, recurvos, base estreita; lenticelas lineares a circulares, cremes, adensadas. Gemas protegidas por catáfilos imbricados, estreitamente triangulares. Estípulas persistentes, $2-4 \times 0,5-1 \mathrm{~mm}$, triangulares, tomentosas. Folhas 2-5 pares de folíolos; pecíolo 0,2-3 cm compr., pubescente a tomentoso, sem nectário; espículas subuladas a lineares entre cada par de foliólulos, raque 0,6-3,2 cm compr., pubescente, sem nectários. Folhas com 2-5 pares de folíolos; foliólulos 5-24; ráquila $0,7-3 \mathrm{~cm}$ compr., sulcada, parafilídios subulados; lâmina 2,5-6×1-1,5 $\mathrm{mm}$, estreitamente oblonga, base oblíqua, ápice arredondado, margem ciliada, glabra em ambas as faces, nervura principal subcêntrica a excêntrica, secundárias pouco conspícuas na face abaxial e inconspícuas na face adaxial. Pedúnculo $5-8 \mathrm{~mm}$ compr., pubescente; bráctea $2-3 \times 0,5-1 \mathrm{~mm}$, triangular, pubescente; bractéola $1-1,2 \times 0,25-0,4$, triangular, pubescente. Espiga cilíndrica, 3,5-5 cm compr., axilar. Flores todas andróginas, tetrâmeras, sésseis; cálice 0,5-1 × 0,5-1 mm, campanulado, glabro a pubescente, lobos triangulares; corola 1-2 $\times$ 0,5-1 mm, campanulada, glabra, branca, lobos triangulares; estames 8, filetes 8, 4-5 mm compr., brancos, antera globosa sem glândulas apicais; ovário elíptico, estipitado, óvulo por lóculo 7, estilete $1 \mathrm{~mm}$ compr. estigma filiforme. Craspédios ca. 5,7 $\times 0,5-0,8 \mathrm{~cm}, 4-8$ artículos, sésseis, planocompressos, estreitamente oblongos, com ou sem constrições, margem reta, glabros a puberulentos, marrom-esverdeados. Sementes 2,5-4 × 2-3,5 mm, orbiculares, não aladas, plano-compressas, marrons. Material examinado: Serra Talhada, Estação Experimental do IPA-Lauro Bezerra, 19.V.2010, fr., T.G.C. Menezes et al. 88 (HESBRA); 22.III.2010, fr., T.G.C. Menezes 40 (HESBRA); 28.04.1995, fl., E. Sampaio 409 (PEUFR); 22.III.1995, fl., M.L. Gomes et al. 9 (IPA); Estação Experimental do IPA, 1991 fl., R. Pereira 53808 (IPA); Estação Experimental do IPA -
Lauro Bezerra, 2010, fr., I.S.G. Sá 4 (HESBRA); mirante no topo da Serra Talhada, 9.VII.2015, fr., P.E.M. Santos 2 (HESBRA); PEMP, VI.2010, fr., T.G.C. Menezes 147 (HESBRA); Serra Branca, 3.VI.2010, fr., R.S. Cordeiro et al. 110 (HESBRA); próximo ao Açudezinho, 9.VI.2016, fr., I.S. Santana 1 (HESBRA); topo próximo às antenas, 2.VI.2016, fr., I.N.S. Aquino 1 (HESBRA).

Nome popular: jurema ou jurema-branca.

Espécie endêmica do Brasil, presente no Nordeste (BA, CE, PB, PE e RN) e Sudeste (MG), exclusivamente no domínio Caatinga (Santos-Silva et al. 2015; BFG 2018). É encontrada na beira de estradas do PEMP, frequente em solos pedregosos e sobre afloramentos rochosos. Floresce e frutifica praticamente o ano inteiro.

Mimosa ophthalmocentra é reconhecida por um conjunto de caracteres, hábito arbustivo, foliólulo sem pontuações glandulares na face abaxial, inflorescência em espiga cilíndrica, predominantemente branca e craspédio séssil. Assemelha-se morfologicamente a $M$. arenosa var. arenosa e $M$. tenuiflora também presentes no PEMP e os caracteres distintivos entre estas espécies são apresentados nos comentários da primeira espécie.

Ilustrações: Queiroz (2009) e Santos-Silva et al. (2015).

5.5 Mimosa pigra L. var. pigra, Cent. Pl. I 13-14. 1755.

Fig. $2 g$

Arbusto ereto 1,5 m alt.; ramos marrons, estriados, híspidos, aculeados, indumento ferrugíneo. Acúleos esparsos, nodais e internodais e na raque, ligeiramente incurvos, sem lenticelas. Gemas protegidas por catáfilos triangulares. Estípulas persistentes, 3-7 × 0,5-2 mm, ovallanceoladas a triangulares, híspidas. Folhas 8-11 pares de folíolos; pecíolo 0,6-1 cm compr., híspido, sem nectário; espículas espinescentes entre cada par de folíolos; raque 2-12 cm compr., híspida, aculeada, sem nectários; foliólulos 12-90; ráquila 3,5-15 cm compr., triangular, sem parafilídios; lâmina 1-6×0,5-1 mm, estreitamente elíptica, base oblíqua, ápice agudo, margem ciliada, face abaxial serícea, face adaxial glabra, sem pontuações, nervura principal cêntrica a subcêntrica, secundárias conspícuas na face abaxial e pouco conspícuas a inconspícuas na face adaxial. Pedúnculo 0,5-3,5 cm compr., híspidos; bráctea 2-3 × 1-2 mm, lanceolada, pubescente; bractéola 2-3 ×0,5-1 mm, romboide, pubescente. Espiga globosa, $1-5 \mathrm{~cm}$ diâm., axilar. Flores todas andróginas, tetrâmeras, sésseis; cálice 1-2 × 0,5-1 mm, campanulado, glabro, lobos triangulares; corola 3-3,5 × 1-1,5 mm, 
campanulada, pubescente, rósea, lobos triangulares; estames 8, filetes 6-8 mm compr., amarelos, antera oblongoide sem glândulas apicais; ovário elíptico, óvulo por lóculo 8-10, estilete 2,5 mm compr., estigma filiforme. Craspédios 3,5-8 × 1-1,4 cm, 7-20 artículos, estreitamente oblongos, sésseis, margem reta, híspidos, castanho-esverdeados. Sementes 5-6 × 1,5-2 mm, estreitamente oblongas, não aladas, não plano-compressas, verde-claro.

Material examinado: Serra Talhada, Fazenda Saco, Açude Saco I, 24.IV.2012, fr., W. Cordeiro et al. 249 (HESBRA); leito do rio Pajeú próximo à ponte de acesso a Caxixola, 19.XII.2012, fl., W. Cordeiro et al. 379 (HESBRA).

Material adicional: BRASIL. PERNAMBUCO: Bonito, s.d., fl., A.G. da Silva et al. 469 (PEUFR); Triunfo, Estrada para Santa Cruz, Fazenda Bom Jesus, 26.II.1986, fl., V.C. Lima et al. $61 \mathrm{~A}$ (IPA).

Variedade distribuída na região Neotropical e na África (Queiroz 2009). Tem ampla distribuição no Brasil e está presente em todas as regiões, na maioria dos estados brasileiros, exceto no Rio Grande do Sul. Ocorre nos domínios Amazônico, Caatinga, Cerrado, Atlântico e Pantanal (BFG 2018). Na Caatinga, é uma planta com distribuição associada a cursos d'água (Queiroz 2009). No PEMP, foi observada apenas às margens do açude do Saco. Floresce e frutifica em abril.

Mimosa pigra var. pigra é facilmente identificável pelo indumento híspido ferrugíneo nos ramos, folhas e craspédios, pelos acúleos nos ramos e na raque foliar e craspédios com 7-20 artículos.

Ilustrações: Queiroz (2009).

5.6 Mimosa tenuiflora (Willd.) Poir., Encycl. Suppl. 1(1): 82. 1810.

Fig. 2h,i

Arbusto a árvore 2-4,5 m alt.; ramos marrons escuros, cilíndricos, puberulentos, aculeados, indumento esbranquiçado. Acúleos esparsos, internodais, recurvos, base alargada, lenticelas lineares a circulares, cremes, adensadas. Gemas protegidas por catáfilos imbricados, glandulares, triangulares a deltóides. Estípulas persistentes, 1-3 $\times$ 0,5-0,8 mm, triangulares, pubescentes. Folhas 3-6 pares de folíolos; pecíolo 5-15 mm compr., pubescente com tricoma glandular, sem nectário, espículas subuladas entre cada par de foliólulos; raque 0,6-3 cm compr., puberulenta, sem nectários; foliólulos 8-46; ráquila $1-4,5$ cm compr., canaliculada, parafilídios subulados; lâmina 3-6,5 × 1-2 mm, estreitamente oblonga, base oblíqua, ápice redondo apiculado, margem inteira a ligeiramente crenada, face abaxial puberulenta, face adaxial glabra a puberulenta, pontuações glandulares na face abaxial, nervura principal excêntrica, secundárias inconspícuas em ambas as faces. Pedúnculo 2-20 mm compr., puberulento; bráctea ca. $1 \times 0,5 \mathrm{~mm}$, rombóide, pubescente; bractéola $1-1,2 \times 0,5-0,8$ $\mathrm{mm}$, oblanceolada a obtrulada, pubescente. Espiga cilíndrica, 3-7,5 cm, axilar; inflorescências latentes simultaneamente com as espigas expandidas ou até mesmo com infrutescências. Flores todas andróginas, tetrâmeras, sésseis; cálice 0,8-1,2 × 1-1,2 mm, 4-angulado, glabro a puberulento, lobos triangulares; corola 1-3 × 1-1,2 mm, campanulada, glabra, branca, lobos triangulares; estames 8 , filetes 2-3 mm compr., brancos, antera globosa sem glândulas apicais; ovário elíptico, estipitado, óvulo por lóculo, 8-10, estilete 1, estigma filiforme. Craspédios 3-4 × 0,6-0,7 cm, 5-7 artículos, estipitados, estreitamente oblongos, margem reta, puberulentos, tricomas glandulares sésseis e estipitados, castanho-esverdeados, artículos inflados na região das sementes; estípite 0,3-0,6 mm compr. Sementes 2-3 × 0,9-1 mm, orbiculares, não aladas, plano-compressas, marrons.

Material examinado: Serra Talhada, Açude do Saco, 7.IX.1993, fl., F. Gallindo et al. 55075 (IPA); Estação Experimental do IPA-Lauro Bezerra, 28.04.1995, fl., E.L. Araújo et al. 417 (PEUFR); 28.04.1995, fl., E. Sampaio et al. 412 (PEUFR); 28.III.1995, fl., M.L. Gomes et al. 16 (IPA); 18.XI.2010, fl. e fr., R.S. Cordeiro 157 (HESBRA); 22.III.2010, fl., T.G. Menezes et al. 62 (HESBRA); mirante no topo da Serra Talhada, 9.VII.2015, fl., P.E.M. Santos 3 (HESBRA); PEMP, Lago Pimenteira I, 30.V.2012, fl., W. Cordeiro 319 (HESBRA); próximo ao Açudezinho, 9.VI.2016, fl. e fr., I.S. Santana 2 (HESBRA); Serra Branca, 26.VIII.2009, fl., G.P. Souza (HESBRA 1549).

Material adicional: BRASIL. PERNAMBUCO: Santa Cruz da Baixa Verde, Olho d'Água, Serra da Madeira, 3.VIII.2013, fl. e fr., L. Maciel-Júnior et al. 30 (HESBRA).

Nome popular: jurema preta.

Espécie encontrada em florestas secas no Brasil, Colômbia, El Salvador, Honduras, México e Venezuela (Barneby 1991, Santos-Silva et al. 2015). No Brasil, está presente apenas na região Nordeste (AL, BA, CE, PB, PE, PI, RN, SE), nos domínios Caatinga e Cerrado (Santos-Silva et al. 2015; BFG 2018). Possui ampla distribuição no PEMP, tanto em locais preservados quanto degradados, surgindo muitas vezes como uma planta pioneira após desmatamento, fato também mencionado por Queiroz (2009). É observada sobre solos argilo-arenosos e afloramentos rochosos, em altitudes de 500 a $800 \mathrm{~m}$. Floresce e frutifica praticamente o ano inteiro. 
Mimosa tenuiflora pode ser reconhecida pela união de caracteres como, hábito arbustivo, foliólulos com pontuações glandulares, inflorescência em espiga, flores brancas e craspédios estipitados (estípite 0,3-0,6 cm compr.). Está morfologicamente relacionada a $M$. arenosa var. arenosa e M. ophthalmocentra diferenciandose por caracteres dispostos nos comentários da primeira destas espécies.

Ilustrações: Queiroz (2009), Dourado et al. (2013) e Santos-Silva et al. (2015).

6. Neptunia Lour., F1. Cochinch. 641, 653-654, 1790.

Gênero com distribuição pantropical e aproximadamente 12 espécies (Lewis et al. 2005). São reconhecidas três espécies para o gênero no Brasil, distribuídos nos domínios Amazônico, Caatinga, Cerrado, Atlântico e Pantanal (SantosSilva 2019). No local de estudo foi observada apenas Neptunia plena (L.) Benth.

6.1 Neptunia plena (L.) Benth., J. Bot. (Hooker) 4(31): 355. 1841.

Fig. $2 \mathrm{j}-1$

Erva prostrada; ramos vináceos, às vezes, esponjosos, cilíndricos, glabros, inermes, sem lenticelas. Gemas protegidas por catáfilos imbricados, triangulares a deltóides. Estípulas persistentes, 3-8 $\times 2-4 \mathrm{~mm}$, auriculadas, glabras a raro pubescentes. Folhas 2-3 pares de folíolos; pecíolo 6-30 mm compr., glabro, sem nectário, sem espículas; raque $0,4-4 \mathrm{~cm}$ compr., glabra a raro pubescente, nectário entre o primeiro par de folíolos, nectário 1, orbicular, elevado côncavo; foliólulos 20-48; ráquila $0,5-6 \mathrm{~cm}$ compr., triangular, sem parafilídios; lâmina 2-15 × 0,7-2,5 mm, estreitamente oblonga, base oblíqua, ápice redondo apiculado, margem inteira a ciliada, em ambas as faces glabra, sem pontuações, nervura principal excêntrica, secundárias inconspícuas em ambas as faces. Pedúnculo $1-15,5 \mathrm{~cm}$ compr., glabro; bráctea 4-7 × 2-5 mm, auriculada, glabra a raro pubescente; sem bractéola. Espiga globosa, heteromórfica, 6-15,5 cm compr., axilar, subglobosa. Flores heteromórficas, andróginas centrais, pentâmeras, sésseis; cálice 2-3 × 2-3 $\mathrm{mm}$, campanulado, glabro a pubescente, lobos triangulares; corola 4-5 × 1-1,25 mm, campanulada, glabro a pubescente, verde-claro, lobos triangulares; estames 9-10, filetes 6-8 mm compr., brancos, antera globosa, glândula apical presente; ovário elíptico, óvulo por lóculo 8-12; estilete $2 \mathrm{~mm}$ compr., estigma filiforme. Flores estéreis marginais, estaminódios estreitamente elípticos, laminares, amarelo-ouro.
Folículos 1-2,5 × 0,5-1 cm, estipitados, oblongos, ápice apiculado, margem reta, raros pubescentes, marrons; estípite $0,3-0,5 \mathrm{~cm}$ compr. Sementes 3-2 $\times 1,5-2 \mathrm{~mm}$, estreitamente elípticas, não aladas, plano-compressas, marrom escuras.

Material examinado: Serra Talhada, Fazenda Saco, açude Saco I, 22.III.2012, fl. e fr., W. Cordeiro et al. 211 (HESBRA); margem do açude Saco, Fazenda Saco, 11.XI.2011, fr., $W$. Cordeiro et al. 376 (HESBRA); PEMP, Lagoa Pimenteira II, 19.XI.2011, fl., W. Cordeiro et al. 120 (HESBRA); próximo ao Açudezinho, 9.VI.2016, fl., A. Melo 1 (HESBRA); 9.VI.2016, fl. e fr., J.F.N. Araújo 2 (HESBRA).

É considerada uma planta anfíbia (HenrySilva et al. 2010, Araújo et al. 2012), com distribuição desde o sul dos Estados Unidos até o nordeste do Brasil e na Índia (Queiroz 2009). No Brasil, é observada nas regiões Norte (AC, AM, PA), Nordeste (AL, BA, CE, MA, PB, PE, PI, RN, SE) e Centro-Oeste (GO, MS, MT) (Santos-Silva 2019), nos domínios fitogeográficos Amazônico, Caatinga, Cerrado, Atlântico e Pantanal. No PEMP cresce em reservatórios de pequeno e grande porte. Floresce e frutifica em março e julho.

Entre as espécies do PEMP, Neptunia plena destaca-se por ser uma erva prostrada com caule esponjoso, com estípulas auriculadas, nectário entre o primeiro par de folíolos e, principalmente, pela espiga globosa heteromórfica com flores centrais perfeitas, marginais estéreis, estaminódios estreitamente elípticos, laminares de cor amarelo-ouro.

Ilustrações: Queiroz (2009).

7. Parapiptadenia Brenan, Kew Bull. 17(2): 228, 1963.

Parapiptadenia apresenta seis espécies, distribuídas no leste do Brasil (Queiroz 2009). No Brasil, ocorre no domínio Caatinga, Região Nordeste (AL, BA, CE, CE, PB) (Morim 2018b). Parapiptadenia zehntneri foi a única espécie registrada para o PEMP.

7.1 Parapiptadenia zehntneri (Harms) M. P. Lima \& H. C. Lima, Rodriguésia 36(60): 26. 1984.

Fig. $2 \mathrm{~m}$

Árvore $4 \mathrm{~m}$ alt.; ramos marrons, cilíndricos, glabros, inermes; lenticelas elípticas a circulares, cremes, esparsas. Gemas protegidas por catáfilos imbricados, deltóides. Estípulas persistentes, ca. $0,5 \times 0,5 \mathrm{~mm}$, triangulares, pubescentes. Folhas 2-5 pares de folíolos; pecíolo 10-42 mm compr., glabro, nectário 1 , na região mediana do pecíolo, oblongo, plano; sem espículas; raque $1-6,5 \mathrm{~cm}$ compr., glabra, nectário entre o par de folíolos 
distais 1, oblongo, plano; foliólulos 4-16; ráquila 2-5,5 cm compr., canaliculada, sem parafilídios; lâmina 6-30 × 4-12 mm, elíptica, base oblíqua, ápice arredondado, margem inteira, em ambas as faces glabra, sem pontuações, nervura principal cêntrica, secundárias evidentes em ambas as faces. Pedúnculo 0,5-1,1 cm compr., glabro; bráctea ausente; bractéola 0,5-0,6 × 0,3-0,6 $\mathrm{mm}$, triangular, pubescente. Espiga cilíndrica, homomorfica, 4,5-7,5 cm compr., axilar. Flores todas andróginas, pentâmeras, sésseis; cálice ca. 1,5 $\times 1 \mathrm{~mm}$, campanulado, glabro, lobos triangulares; corola ca. 2,5 $\times 1 \mathrm{~mm}$, campanulada, glabra, vermelho-escura, lobos triangulares; estames 8-10, filetes 2-2,5 compr., amarelos, antera globosa, com glândula apical caduca; ovário elíptico, óvulo por lóculo 6; estilete ca. $2 \mathrm{~mm}$ compr., estigma filiforme. Legumes 10-16 × ca. 2,5 cm, estipitados, oblongos, margem reta, glabros, castanho escuro; estípite 0,5-1,5 cm compr. Sementes 7-9 × 5-6 mm compr., largamente elípticas, aladas, alas $1-3 \mathrm{~mm}$ compr., plano-compressas, marrons.

Material examinado: Serra Talhada, Estação Experimental do IPA-Lauro Bezerra, 4.IV.2010, fr., T.G.C. Menezes et al. 67 (HESBRA); PEMP, Córrego Luanda, 4.III.2016, fl. e fr., S.S. Matos et al. 823 (HESBRA).

Nome popular: angico

Espécie endêmica do Brasil, presente na Região Nordeste (AL, BA, CE, PE, PB), no domínio Caatinga (Queiroz 2009; Morim 2018b). No PEMP, ocorre em locais mais preservados. Floresce e frutifica em março e abril.

Parapiptadenia zehntneri é facilmente reconhecida pelas espigas cilíndricas, corola e filetes vermelho-escuros, frutos estipitados com estípite variando 0,5 a 1,5 cm compr., e sementes aladas.

Ilustrações: Queiroz (2009).

8. Piptadenia Benth., J. Bot. (Hooker) 2(11): 135, 1840.

Piptadenia é composto por 24 espécies neotropicais (Luckow 2005). No Brasil ocorrem 21 espécies distribuídas nos domínios fitogeográficos da Amazônia, Caatinga, Cerrado e Mata Atlântica (BFG 2018). Piptadenia stipulacea (Benth.) Ducke foi a única registrada para a área de estudo.

8.1 Piptadenia stipulacea (Benth.) Ducke, Arch. Jard. Bot. Rio de Janeiro 5: 126. 1930. Fig. 2n,o

Arbusto a árvore 1,5-5 $\mathrm{m}$ alt.; ramos castanhos a acizentados, cilíndricos, puberulentos, geralmente aculeados, raro inermes, indumento esbranquiçado. Acúleos nodais e internodais, esparsos, retos ou incurvos, base alargada; lenticelas lineares a circulares, adensadas, creme. Gemas protegidas por catáfilos imbricados, triangulares a deltóides. Estípulas persistentes, 3-5 × 0,25-0,5 $\mathrm{mm}$, triangulares, pubescentes. Folhas 5-8 pares de folíolos; pecíolo 10-50 mm compr., puberulento a pubescente, nectário na região mediana do pecíolo 1-3, elíptico, oblongo a circular, elevado côncavo, sem espículas; raque 5-11 cm compr., tomentosa, sem nectário; foliólulos 26-74; ráquila 1,5-4,5 cm compr., angulosa, parafilídios triangulares; lâmina 2-8 × 0,5-1 mm, estreitamente oblonga, base oblíqua, ápice obtuso a arredondado, margem inteira a ciliada, glabra em ambas as faces, sem pontuações, nervura principal subcêntrica, secundárias pouco evidentes a inconspícuas na face abaxial e conspícuas na face adaxial. Pedúnculo 0,4-0,6 cm compr.; tomentoso; bráctea 3-3,5 $\times 0,8-1 \mathrm{~mm}$, triangular, glabra; bractéola 1-2 $\times 0,4-0,6 \mathrm{~mm}$, triangular, pubescente. Espiga cilíndrica, homomórfica, 1,5-8 cm compr., axilar. Flores todas andróginas, pentâmeras, sésseis; cálice ca. 1,5 × $1 \mathrm{~mm}$, campanulado, glabro; corola $2,5 \times 1 \mathrm{~mm}$, campanulada, glabra, creme, lobos triangulares; estames 8-10, filetes 2-2,5 compr., amarelos, antera globosa com glândula estipitada entre as tecas; ovário elíptico, óvulo por lóculo 6; estilete $2 \mathrm{~mm}$ compr., estigma filiforme. Legumes 4-11 × 1-2 cm, estipitados, oblongos, margem reta, glabros, marrom-claro; estípite $0,3-0,7 \mathrm{~cm}$ compr.. Sementes ca. $5 \times 4 \mathrm{~mm}$, largamente elípticas, marrons, não aladas, plano-compressas.

Material examinado: Serra Talhada, Serra Branca, 26.VIII.2009, fr., F.J.A. Lima (HESBRA 1550); Fazenda Saco, 1.VII.2008, fr., E.F. Silva 31 (HESBRA); Serra Branca, 26.VIII.2009, fr., T.B. Amorim s.n (HESBRA 1557); Estação Experimental do IPA-Lauro Bezerra, 4.IV.2010, fl., T.G.C. Menezes 77 (HESBRA); PEMP, 5.V.2014, fl., J. Rodrigues 1 (HESBRA); Fazenda Saco, Açude Saco I, 24.IV.2012, fl., W. Cordeiro et al. 240 (HESBRA); Serra Branca, 30.III.2009, fl., E.F. Costa 4 (HESBRA); Estação da UFRPE, 7.VI.2005, fr., L.M. Pessoa et al. 256 (PEUFR); Estação Experimental do IPA, Pedra Branca 19.IV.1995, fl., M.L. Gomes et al. 34 (IPA); Mirante no Topo da idem, 9.VII.2015, fr., A.V. Barros et al. 7 (HESBRA); PEMP, próximo ao Açudezinho, 9.VI.2016, fr., W. Martins 1 (HESBRA); topo da Serra Talhada, próximo às antenas, 2.VI.2016, fl., A.M.M. Boaventura 2 (HESBRA); Fazenda Saco, Próximo ao Campus UAST, 2008, fr., G.M.S. Souza 3 (HESBRA); Serra Branca, 22.IX.2009, fr., W.J.S. Diniz 1 (HESBRA).

Nome popular: espinheiro e jurema branca.

Espécie endêmica do Nordeste (AL, BA, CE, $\mathrm{PB}, \mathrm{PE}, \mathrm{PI}, \mathrm{RN}, \mathrm{SE})$, no domínio fitogeográfico 
da Caatinga (BFG 2018). No PEMP, Piptadenia stipulacea é bastante difundida, crescendo tanto em áreas mais preservadas quanto em locais perturbados, ao longo de trilhas e é comum sobre afloramentos rochosos, em altitude de 500 a 800 m. Floresce e frutifica preticamente o ano inteiro.

Piptadenia stipulacea pode ser reconhecida pelos ramos geralmente aculeados, raro, inermes, pela presença de 1-3 nectários na região mediana do pecíolo, inflorescência em espiga cilíndrica e flores pentâmeras. Pode ser confundida com espécies de Mimosa que também tem inflorescência em espiga (M. arenosa var. arenosa, M. ophthalmocentra e $M$. tenuiflora) entretanto, a ausência de nectários no pecíolo e flores tetrâmeras, distinguem estes táxons de $P$. stipulacea.

Ilustrações: Queiroz (2009).

\section{Senegalia Raf., Sylva Tellur. 119, 1838.}

Senegalia compreende cerca de 210 espécies distribuídas nas regiões tropicais e subtropicais (Barros \& Morim 2014). No Brasil, ocorrem 60 espécies encontradas nos domínios fitogeográficos da Amazônia, Caatinga, Cerrado, Mata Atlântica e Pantanal (BFG 2018). Na área de estudo foi registrada Senegalia tenuifolia.

9.1 Senegalia tenuifolia (L.) Britton \& Rose, N. Amer. Fl. 23(2): 118. 1928.

Árvore a arbusto $3 \mathrm{~m}$ alt.; ramos castanhos a acizentados, cilíndricos, pubescentes, aculeados, indumento esbranquiçado. Acúleos nodais ou internodais, recurvados, base alargada; lenticelas lineares, cremes, adensadas. Gemas protegidas por catáfilos imbricados, deltóides. Estípulas persistentes, 2-5 × 0,5-1 $\mathrm{mm}$, lanceoladas a estreitamente triangulares, pubescentes. Folhas 10-20 pares de folíolos; pecíolo 5-25 mm compr., tomentoso, nectário 1 , abaixo da região mediana do pecíolo, cônico, sem espículas; raque 6-13 cm compr., tomentoso, nectário nos pares de folíolos distais 3-4, curto-estipitada peltada, côncava; foliólulos 34-60; ráquila $1-5,3 \mathrm{~cm}$ compr., sulcada, sem parafilídios; lâmina $1-5 \times 0,4-1$ $\mathrm{mm}$, estreitamente oblonga, base oblíqua, ápice agudo, margem ciliada, glabra em ambas as faces, sem pontuações, nervura principal excêntrica, nervuras secundárias inconspícuas em ambas as faces. Pedúnculo 0,5-1,5 cm compr., tomentoso; bráctea $1-2 \times 0,5-0,8 \mathrm{~mm}$, triangular, tomentosa; bractéola $0,5-1 \times 0,7-1 \mathrm{~mm}$, romboide, pubescente. Espiga globosa, homomórfica, 1-2 cm larg., axilar. Flores todas andróginas, pentâmeras, sésseis; cálice ca. 2,5 $\times 1 \mathrm{~mm}$, lobos ovais, glabros; corola ca. 2 $\times 1 \mathrm{~mm}$, campanulada, glabra a raro pubescente, creme, lobos triangulares; estames 80-85, livres, filetes ca. 3-5 mm compr., brancos, antera globosa sem glândulas apicais; ovário fusiforme, óvulo por lóculo 7; estilete 1-1,5 mm compr., estigma filiforme, estaminódios ausentes. Legumes ca. $8,5 \times 2,2 \mathrm{~cm}$, estipitados, estreitamente oblongos, glabros, raro pubescentes, castanhos; estípite 0,2-0,5 cm compr.. Sementes 4,5-10 × 3,5-7 cm, elípticas, não aladas, plano-compressas, marrons. Material examinado: Serra Talhada, Estação Experimental do IPA, 8.XI.1996, fl., M.L. Gomes et al. 134 (IPA); Parque Estadual Mata da Pimenteira, Córrego Luanda, 4.III.2016, fr., S.S. Matos et al. 870 (HESBRA). Material adicional: BRASIL. PERNAMBUCO: Santa Cruz da Baixa Verde, Olho d'água, Serra da Madeira, 21.II.2013, fl., J.M. Novaes et al. 2 (HESBRA); Serra da Madeira, 23.I.2014, fl., P.H.O. Miranda et al. 4 (HESBRA); Triunfo, Mata do Brejinho, propriedade do Sr. Júlio Ramos, 4.II.2013, fl., S.S. Matos et al. 100 (HESBRA); mata próxima ao SESC, 17.VII.2014, fr., J.R.S. Freire et al. 2 (HESBRA).

Espécie com ampla distribuição na América do Sul, onde ocorre desde das Guianas até o Paraguai (Queiroz 2009). No Brasil, ocorre na Região Norte (AC, AM, PA), Nordeste (BA, PB, PE), Centro-Oeste (GO, MT), Sudeste (MG, RJ, SP) e Sul (PR, SC) (BFG 2018). No PEMP, poucos indivíduos desta espécie foram encontrados nas áreas com baixa altitude $(500-600 \mathrm{~m})$, geralmente em margem de riachos. Em altitudes mais elevadas, é comumente observada formando densa população. Floresce e frutifica em março e outubro.

Senegalia tenuifolia diferencia-se das demais espécies do clado Mimosoide do PEMP pelo seguinte conjunto de caracteres: ramos aculeados, nectários na base do pecíolo e entre os pares de folíolos distais, inflorescência globosa e estames numerosos (80-85). No material herborizado, às vezes $S$. tenuifolia, é confundida com Anadenathera colubrina, mas podem ser diferenciadas, principalmente, pelo número de foliólulos por folha 34-60 (vs. 70-140) e de estames 80-85 (vs. 10).

Ilustrações: Queiroz (2009) e Barros \& Morim (2014).

\section{Agradecimentos}

À Coordenação de Aperfeiçoamento de Pessoal de Nível Superior - CAPES pela concessão de bolsa de mestrado a primeira autora, vinculada ao projeto "Leguminosae Adans. do Parque Estadual Mata da Pimenteira, Serra Talhada, Pernambuco". 
Aos curadores e aos técnicos dos Herbários visitados pela atenção e acolhimento durante a consulta das coleções. Ao Rodolfo Araújo pela confecção do mapa geográfico da área estudada e aos revisores pelas sugestões feitas ao manuscrito.

\section{Referências}

Altschul S von Reis (1964) A taxonomic study of the genus Anadenanthera. Contributions from the Gray Herbarium of Harvard University 193: 1-65.

Araújo ES, Sabino JHF, Cotarelli VM, Siqueira-Filho JA \& Campelo MJA (2012) Riqueza e diversidade de macrófitas aquáticas em mananciais da Caatinga. Diálogos \& Ciência 32: 229-233.

Barneby RC (1991) Sensitivae Censitae. A description of the genus Mimosa L. (Mimosaceae) in the New World. Memories of the New York Botanical Garden 65: 1835 .

Barros MJF \& Morim MP (2014) Senegalia (Leguminosae, Mimosoideae) from the Atlantic Domain, Brazil. Systematic Botany 39: 452-477.

Barroso GM, Morim MP, Peixoto AL \& Ichaso CLF (1999) Frutos e sementes: morfologia aplicada à sistemática de dicotiledôneas. Editora UFV, Viçosa. $443 p$.

Bentham G (1870) Leguminosae II. Swartzieae et Caesalpinieae. In: Martius CFP (ed.) Flora brasiliensis. Vol. 15. n. 2. Pp. 1-254.

BFG - The Brazil Flora Group (2018) Brazilian Flora 2020: innovation and collaboration to meet Target 1 of the Global Strategy for Plant Conservation (GSPC). Rodriguésia 69: 1513-1527.

Chappill JA (1995) Cladistic analysis of the Leguminosae. In: Crisp M \& Doyle JJ (eds.) Advances in legume systematics. Part 7. Royal Botanic Gardens, Kew. Pp. 1-9.

Córdula E, Queiroz LP \& Alves M (2008) Checklist da flora de Mirandiba, Pernambuco: Leguminosae. Rodriguésia 59: 597-602.

Dourado DAO, Souza AC \& Santos-Silva J (2013) O gênero Mimosa L. (Leguminosae: Mimosoideae) na APA Serra Branca/Raso da Catarina, Bahia, Brasil. Biota Neotropica 13: 225-240.

Doyle JJ, Chappill JA, Bailey CD \& Kajita T (2000) Towards a comprehensive phylogeny of legumes: evidence from $r b c L$ sequences and non-molecular data. In: Herendeen PS \& Bruneau A (eds.) Advances in legume systematics. Part 9. Royal Botanic Gardens, Kew. Pp. 299-310.

Ducke A (1953) As leguminosas de Pernambuco e Paraíba. Memórias do Instituto Oswaldo Cruz 51: 417-461.

Flora do Brasil 2020 em construção. Jardim Botânico do Rio de Janeiro. Disponível em < http://floradobrasil. jbrj.gov.br/ > . Acesso em 25 janeiro 2018.
Henry-Silva GG, Moura RST \& Dantas LLO (2010) Richness and distribution of aquatic macrophytes in Brazilian semi-arid aquatic ecosystems. Acta Limnologica Brasiliensia 22: 147-156.

Köppen W (1948) Climatologia: con un studio de los climas de la tierra. Fondo de Cultura Económica, Ciudad del México. 478p.

Lewis GP (1987) Legumes of Bahia. Royal Botanic Gardens, Kew. 369p.

Lewis G, Schrire B, Mackinder B \& Lock M (2005) Legumes of the world. Royal Botanic Gardens, Kew. 577p.

LPWG - The Legume Phylogeny Working Group (2013) Legume phylogeny and classification in the $21 \mathrm{st}$ century: Progress, prospects and lessons for other species-rich clades. Taxon 62: 217-248.

LPWG - The Legume Phylogeny Working Group (2017) A new subfamily classification of the Leguminosae based on a taxonomically comprehensive phylogeny. Taxon 66: 44-77.

Luckow M (1993) A monograph of Desmanthus (Mimosoideae: Leguminosae. Systematic Botany Monographs 38: 1-166.

Luckow M (2005) Tribe Mimoseae. In: Lewis G, Schrire BD, Mackender B \& Lock M (eds.) Legumes of the world. Royal Botanic Gardens, Kew. Pp. 163-183.

Melo Y, Córdula E, Machado SR \& Alves M (2010) Morfologia de nectários em Leguminosae sensu lato em áreas de caatinga no Brasil. Acta Botanica Brasilica 24: 1034-1045.

Melo AL, Lima ALA, Menezes TGC, Cordeiro RS, Santos ES, Farias SGG, Silva FV, Caldas DRM, Matos SS, Melo R, Lima LR, Cordeiro WPS, Gomes APS \& Rodal MJN (2013). Flora vascular terrestre. In: Santos EM, Melo-Júnior M, Silva-Cavalcanti JS \& Almeida GVL (eds.) Parque Estadual Mata da Pimenteira: riqueza natural e conservação da Caatinga. EDUFRPE, Recife. Pp. 83-103.

Mesquita AL (1990) Revisão taxonômica do gênero Enterolobium Mart. (Mimosoideae) para a região neotropical. Dissertação de Mestrado. Universidade Federal Rural de Pernambuco, Recife. 222p.

MMA - Ministério do Meio Ambiente (2002) Avaliação e identificação de áreas e ações prioritárias para a conservação, utilização sustentável e repartição dos benefícios da biodiversidade nos biomas brasileiros. 1. Meio ambiente. 2. Biodiversidade. 3. Política ambiental. I. Ministério do Meio Ambiente. MMA/ SBF, Brasília. 404p.

Mori AS, Silva LAM, Lisboa G \& Coradin L (1989) Manual de manejo do herbário fanerogâmico. Centro de Pesquisa do Cacau, Ilhéus. 104p.

Morim MPS (2018a) Anadenanthera. In: Flora do Brasil 2020 em construção. Jardim Botânico do Rio de Janeiro. Disponível em $<$ http://floradobrasil.jbrj. 
gov.br/reflora/floradobrasil/FB22782>. Acesso em 25 janeiro 2018.

Morim MP (2018b) Parapiptadenia. In: Flora do Brasil 2020 em construção. Jardim Botânico do Rio de Janeiro. Disponível em $<$ http://floradobrasil.jbrj. gov.br/reflora/floradobrasil/FB18916>. Acesso em 25 janeiro 2018.

Morim MP, Mesquita AL \& Bonadeu F (2018) Enterolobium. In: Flora do Brasil $2020 \mathrm{em}$ construção. Jardim Botânico do Rio de Janeiro. Disponível em <http://floradobrasil.jbrj.gov.br/ reflora/floradobrasil/FB22961>. Acesso em 25 janeiro 2018.

Peterle PL, Chagas AP, Thomaz LD, Dutra VF \& Valadares RT (2015) Mimosoideae (Leguminosae) do Parque Estadual Paulo César Vinha, Espírito Santo, Brasil. Rodriguésia 66: 245-257.

Persson C (2001) Phylogenetic relationships in Polygalaceae based on plastid DNA sequences from the trnL-F region. Taxon 50: 763-779.

Polhill RM, Raven PH \& Stirton CH (1981) Evolution and systematics of the Leguminosae. In: Polhill RM \& Raven PH (eds.) Advances in legume systematics. Part 1. Royal Botanic Gardens, Kew. Pp. 1-26.

Queiroz LP (2009) Leguminosas da Caatinga. EUEFS, Feira de Santana. 441p.

Radford AE, Dickison WC, Massey R \& Bell CR (1974) Vascular plant systematics. Harper \& Row, New York. 891p.

Santos EM, Almeida GVL, Oliveira LLDSS, Menezes ERA, Guedes MV, Sacramento AN, Bezerra GSCL, Brito JVA \& Santos JCO (2013) Parque Estadual Mata da Pimenteira - Primeira Unidade de Conservação Estadual na Caatinga de Pernambuco. In: Santos EM, Melo-Júnior M, Silva-Cavalcanti JS \& Almeida GVL (eds.) Parque Estadual Mata da Pimenteira: riqueza natural e conservação da Caatinga. EDUFRPE, Recife. Pp. 15-26.

Santos-Silva J, Simon MF \& Tozzi AMGA (2015) Revisão taxonômica das espécies de Mimosa ser. Leiocarpae sensu lato (Leguminosae Mimosoideae). Rodriguésia 66: 95-154.
Santos-Silva J (2019). Neptunia. In: Flora do Brasil 2020 em construção. Jardim Botânico do Rio de Janeiro. Disponível em <http://floradobrasil.jbrj. gov.br/reflora/floradobrasil/FB83496>. Acesso em 30 janeiro 2019

Silva TGF \& Almeida AQ (2013) Climatologia e características geomorfológicas. In: Santos EM, Melo-Júnior M, Silva-Cavalcanti JS \& Almeida GVL (eds.) Parque Estadual Mata da Pimenteira: riqueza natural e conservação da Caatinga. EDUFRPE, Recife. Pp. 29-36.

Souza ER (2018) Chloroleucon. In: Flora do Brasil 2020 em construção. Jardim Botânico do Rio de Janeiro. Disponível em $<$ http://floradobrasil.jbrj. gov.br/reflora/floradobrasil/FB22878>. Acesso em 25 janeiro 2018.

Simon MF, Grether R, Queiroz LP, Särkinen TE, Dutra VF \& Hughes CE (2011) The evolutionary history of Mimosa (Leguminosae): toward a phylogeny of the sensitive plants. American Journal of Botany 98: 1201-1221.

Simpson MG (2006) Plant systematics. Elsevier Academic Press, Amsterdam. 752p.

Tabarelli M \& Silva JMC (2002) Áreas e ações prioritárias para a conservação, utilização sustentável e repartição de benefícios da biodiversidade do bioma Caatinga. In: Araújo EL, Moura AN, Sampaio ESB, Gestinari LMS, Carneiro JMT (eds.) Biodiversidade, conservação e uso sustentável da flora do Brasil. UFRPE/SBB, Imprensa Universitária, Recife. Pp. 47-52.

Thiers B [continuously updated]. Index herbariorum: aglobal directory of public herbaria and associated staff. New York Botanical Garden's Virtual Herbarium. Disponível em $<$ http://sweetgum.nybg. org/ih/>. Acesso em 23 julho 2017.

Wojciechowski MF, Lavin M \& Sanderson MJA (2004) Phylogeny of Legumes (Leguminosae) based on analysis of the plastid mat $\mathrm{K}$ gene resolves many well-suported subclades within the family. American Journal of Botany 9: 1846-1862. 